\title{
THE IMPACT OF MIGRANT TUBERCULOSIS ON THE CHIMIORESISTANCE PATTERN OF ANTITUBERCULOSIS DRUGS IN A LOW BURDEN TUBERCULOSIS EUROPEAN COUNTRY
}

\author{
OANA-CRISTINA ARGHIR ${ }^{1,2}$, PEDRO MANUEL ALVES PEREIRA ${ }^{3}$, AGRIPINA RAȘCU $^{4 *}$, \\ ELENA DANTES ${ }^{1,2}$, ERDIN BORGAZI ${ }^{2}$, DAN MARCEL ILIESCU ${ }^{1}$, MARINA RUXANDRA \\ OȚELEA $^{4}$, SIMONA CLAUDIA CAMBREA ${ }^{1}$ \\ ${ }^{1}$ Medicine Faculty, “Ovidius” University of Constanța, 124 Mamaia Blvd, 900527 Constanța, Romania \\ ${ }^{2}$ Clinical Hospital of Pneumophthisiology, 40 Sentinelei Street, 900002 Constanța, Romania \\ ${ }^{3}$ Fellow-in Training Hospital de Faro, Algarve, Portugal \\ 4 "Carol Davila” University of Medicine and Pharmacy Bucharest, Dionisie Lupu Street, sector 1, 030167, Bucharest, \\ Romania
}

*corresponding author: agrirascu@yahoo.com

Manuscript received: January 2018

\begin{abstract}
The issue of drug resistance (DR) among patients with tuberculosis (TB) has occurred since the introduction of streptomycin and becomes a priority for TB control programs worldwide. Based on Portugal National Tuberculosis Surveillance System (SVIG-TB) and regional drug sensitivity testing (DST) database, a 10 year-epidemiological survey described retrospectively the impact of DR phenomenon on TB trend in Algarve, Portugal, from 01 January 2004 to 31 December 2014. Study sample included 106 patients with male $(78 \%)$ and youth predominance. The most important risk factor for DR-TB consisted in immigration (31.13\%).
\end{abstract}

\section{Rezumat}

Problema chimiorezistenței, la pacienții cu tuberculoză (TB), a apărut odată cu introducerea streptomicinei și a devenit o prioritate a programelor de control al TB în întreaga lume. Pe baza datelor statistice oferite de Programul Național de Supraveghere a TB din Portugalia și de Registrul regional de investigare a sensibilității tulpinilor de micobacterii TB din regiunea Algarve la medicamentele anti-TB, s-a evaluat impactul rezistenței medicamentoase asupra evoluției endemiei TB, din această regiune, pe o perioadă de 10 ani (01 ianuarie 2004 până în 31 decembrie 2014). Eșantionul a inclus 106 pacienți, cu predominanța bărbaților (78\%) și a adulților tineri. Cel mai important factor de risc al TB-DR a fost migrația (31,13\%).

Keywords: first line tuberculostatic drugs, migrant tuberculosis, drug-resistance

\section{Introduction}

Tuberculosis (TB) is still considered one of the major health problems on Earth, responsible for annually illness and deaths among millions of people, having a strong fatal correlation with poverty, developing countries [1], weakened immune system in patients with human immunodeficiency virus (HIV) infection, malnutrition, diabetes, drug-resistance, alcohol and drug abuse, non-compliance, failure of therapy, other immunosuppressive conditions and comorbidities [2, 3]. According to World Health Organization (WHO), in 2013, there were reported 9.0 million new cases of TB illness and 1.5 million deaths, as well as 480,000 people with multidrug-resistant TB (MDRTB), developed in the same year [4]. Resistance emergence of Mycobacterium tuberculosis (MTB) against anti-TB drugs was progressively observed, after the discovery of streptomycin [5]. The development of new anti-TB drugs could not avoid the development of MTB resistant strains. The occurrence of drug resistant tuberculosis (DR-TB) became a real human threat, including a large spectrum of resistance: mono-, poly-, multi-drug-resistance, extensively drug-resistance (XDR), or extremely drug resistance (XXDR), representing a red flag of burden TB even for developed countries because of the impact of HIV/AIDS pandemic, increased immigration and drug intravenous abuse [6]. The massive flow of migrant people across Europe, in the era of globalization, may contribute to a higher spread of TB infection, across geographic boundaries, to the virgin population of low TB burden countries $[7,12]$. The idea of progressive evolving TB with resistant MTB strains against first line anti-TB drugs, throughout migration phenomenon, may provide new insights in the design of future European TB burden scenarios, including TB in children and adolescents, which still remains a "neglected area of research" $[8,16]$. 
FARMACIA, 2018, Vol. 66, 3

The aim of this paper is to identify the drug resistance pattern of the first line anti-TB drugs, treatments outcomes and risk factors of notified DRTB cases in a low TB burden area, Southern region of Portugal, Algarve.

\section{Materials and Methods}

\section{Patients}

A 10 years analysis assessed retrospectively DR phenomenon on TB trend in Algarve, Portugal, from 01 January 2004 to 31 December 2014. All pulmonary TB notified cases, and drug sensitivity tested, were identified by consulting the Portugal National Tuberculosis Surveillance System (SVIG-TB) and regional drug sensitivity testing (DST) database. The formulary 1 (Registration of new cases of TB and relapses) and 2 (Complementary data associated with the registration and the outcome of finished therapy) were analysed. Patients with first resistance against anti-TB agents were included. Demographic characteristics of cases, risk factors of DR-TB disease, drug sensitivity testing (DST) for the first line drugs and epidemiologic profile of DR-TB were all assessed for a better understanding of DRTB trends in Algarve, Portugal. According to the last WHO definitions [9], the following operational definitions of DR-TB were used: rifampicin resistant TB excluded resistance to isoniazid; poly-resistant TB cases included cases with resistance to more than one medicine from the first line group, excluding isoniazid $(\mathrm{H})$ and rifampicin (R). MDR-TB included MTB resistance against the most effective antiTB drugs, namely isoniazid and rifampicin. In order to respect the ethical considerations, the assessment of DR-TB evidence respected the anonymity of all DR-TB patients.

Statistical analysis

All data for descriptive analysis were coded, entered and then analysed using Epi info statistical software

programme version 7 , calculating odds ratio $(\mathrm{OR})$ and risk ratio $(R R)$ for a level of significance of $p<0.05$.

\section{Results and Discussion}

106 DR-TB cases (87 new cases and 16 relapses) were identified, with male predominance $(n=83$ cases; $78 \%$ ), and a gender ratio of $3.6 \mathrm{M} / 1 \mathrm{~F}$. The peak distribution of DR-TB notifications was observed among young adults $25-34$ years-old $(\mathrm{n}=28$; 26.41\%) (Figure 1).

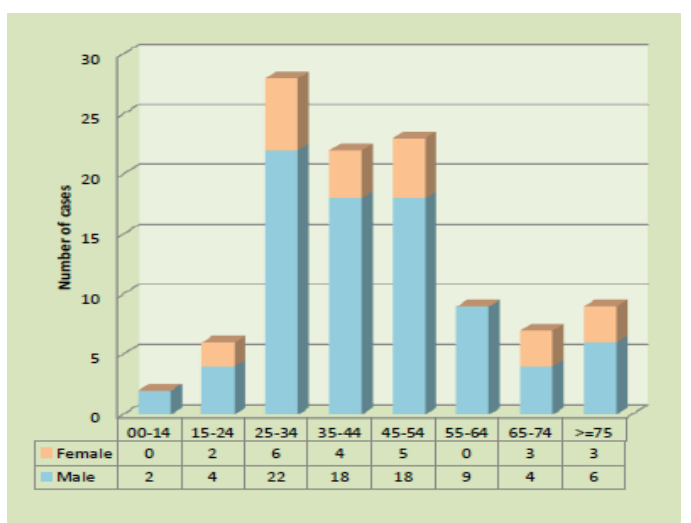

Figure 1.

Distribution of DR-TB cases $(n=106)$ by age and gender

According to the incidence, two major risk factors of DR-TB was immigration $(\mathrm{n}=33$ cases; $31.13 \%)$ and immunosuppression caused by HIV coinfection $(\mathrm{n}=30 ; 28.3 \%)$ (Table I). Both migrant DR-TB and HIV coinfected cases had male predominance, although not statistically significant $\left(\chi^{2}=0.2072 ; p<0.7\right) .8$ cases had unknown HIV status because they refused HIV screening. Other risk factors of DR-TB were: alcohol abuse $(\mathrm{n}=23)$, intravenous drug addiction $(\mathrm{n}=21)$, other drug dependence $(\mathrm{n}=12)$, homeless $(n=4)$ and institutionalization of elderly $(n=3)$.

Table I

The distribution of risk factors of DR-TB

\begin{tabular}{|c|c|c|c|}
\hline Risk factors & Male (M) & Female (F) & M + F \\
\hline Immigrants & 26 & 7 & 33 \\
\hline HIV/AIDS & 24 & 6 & 30 \\
\hline Alcohol dependence & 21 & 2 & 23 \\
\hline IV drug dependence & 18 & 3 & 21 \\
\hline Other drug dependence & 9 & 3 & 12 \\
\hline Communitary residence & 4 & 1 & 5 \\
\hline Homeless & 3 & 1 & 4 \\
\hline Institutionalised & 2 & 1 & 3 \\
\hline
\end{tabular}

The origin of foreign born DR-TB patients was represented by different countries: Ukraine $(n=9$; $28 \%$ ), Moldova $(\mathrm{n}=6 ; 18 \%)$, Romania and Bulgaria with equal number of cases $(n=4 ; 12 \%)$, United Kingdom $(\mathrm{n}=3 ; 9 \%)$, Brazil $(6 \%)$ and African countries (15\%). More than a half of DR-TB patients $(\mathrm{n}=57 ; 54 \%)$ had fibro cavitary advanced form of
Pulmonary Secondary TB disease. Nodular pattern of Pulmonary TB disease was diagnosed in a few cases $(\mathrm{n}=38 ; 36 \%)$. Normal chest X-ray was associated with DR-TB in 8 cases $(7 \%)$, and $3 \%$ of patients were not radiological investigated. Bacteriological exam revealed high contagious DR-TB in $87.37 \%$ of cases $(n=90 / 103)$ consisting in positive smears 
FARMACIA, 2018, Vol. 66, 3

and cultures. The pattern of DR-TB included 10 MDR-TB cases $(9.7 \%)$ and one XDR-TB, 62 cases of mono-resistance $(60.19 \%)$, with the predominance of isoniazid-resistant TB cases $(\mathrm{n}=52 / 62 ; 83.87 \%)$ versus rifampicin-resistant TB cases $(\mathrm{n}=2 / 62 ; 3.22 \%)$. MDR/XDR-TB had an obvious migrant pattern $(\mathrm{n}=$ $8 / 33 ; 24.24 \%$ ) versus native inhabitants of Portugal $(\mathrm{n}=3 / 73 ; 4.1 \%)\left(\mathrm{OR}=7.4667 ; \mathrm{RR}=5.8990 ; \chi^{2}=\right.$ $9.811 ; \mathrm{p}<0.002)$. Treatment outcomes were favourable, with a high rate of success in $73.58 \%$ cases, especially in women $(\mathrm{n}=20 / 23 ; 86.96 \%)$ compared to men $(n=58 / 83 ; 69.88 \%)\left(\chi^{2}=2.6765\right.$; $\mathrm{p}<0.2$ ) (Table II).

Table II

The distribution of DR-TB treatment outcomes

\begin{tabular}{|c|c|c|c|}
\hline Treatment outcome & Male & Female & Total cases \\
\hline Cases & 83 & 23 & 106 \\
\hline Cured & $9(10.84 \%)$ & $1(4.35 \%)$ & $10(9.43 \%)$ \\
\hline Completed & $49(59 \%)$ & $19(82.61 \%)$ & $68(64.15 \%)$ \\
\hline Death & $5(6 \%)$ & 0 & $5(4.71 \%)$ \\
\hline Failure & 0 & 0 & 0 \\
\hline Default (lost to follow up) & $15(8 \%)$ & $2(8.7 \%)$ & $17(16 \%)$ \\
\hline Still on treatment & $1(1.2 \%)$ & 0 & $1(0.9 \%)$ \\
\hline Transferred & $4(4.82 \%)$ & $1(4.35 \%)$ & $5(4.71 \%)$ \\
\hline Treatment success & $58(69.88 \%)$ & $20(86.96 \%)$ & $78(73.58 \%)$ \\
\hline
\end{tabular}

The outcomes were similar in immigrant and in native inhabitant groups $\left(\chi^{2}=9.03066 ; \mathrm{p}=0.72\right)$. Death was reported in $4.71 \%(\mathrm{n}=5$; all men $)$ and loss of follow-up in $16 \%(\mathrm{n}=17)$. Although TB incidence is slowly annually declining worldwide, DR-TB has become more and more prevalent in the last 2 decades, arising major challenges in both diagnosis and treatment rate of success [10]. Drug resistance combined with a high prevalence of TB among immigrants, could be considered a real challenge for any national public health systems and a high threat for children, according to the intensity of epidemiological process. According to the Annual Epidemiological Report, published in 2014 by the European Centre For Disease Prevention and Control (ECDC), 68,423 TB cases were noticed, with an overall rate of 13.5 cases per 100.000 European inhabitants, and the highest rates of TB (per 100,000 inhabitants) were reported by "Romania (85.2), Lithuania (59.2), Latvia (48.6), Bulgaria (31.1), Portugal (25.2) and Estonia (21.6)" [11]. Among 31,004 cases drug susceptibility tested (DST), 1,421 were updated with MDR-TB profile and its highest frequency was observed in Romania (530) [11]. Algarve region occupies approximately $150 \mathrm{~km}$ of the Atlantic Ocean coastline and, in 2011, has had almost a quarter of Portugal inhabitants $(451,006)$, among which 76,881 are foreign born people with highest predominance of immigrants from Africa $(\mathrm{n}=20,495)$, Brazil $(\mathrm{n}=$ $10,751)$, United Kingdom ( $\mathrm{n}=8,759)$, Romania ( $\mathrm{n}$ $=5,045)$ [13]. The high immigrant population makes this region an interesting area for the evaluation of the immigrant effect on different health outcomes, including MDR-TB. In this regard, almost a half of all MDR/XDR-TB new cases diagnosed in Algarve had roots in Eastern European countries $(\mathrm{n}=5 / 11 ; 45.45 \%)$ as Censos
Report presented in 2011 (76,881 immigrants and 374,125 Portuguese people in Algarve) [13]. The study reveals similarities of the evolutive patterns of mono-, poli-resistance and MDR/XDR-TB with peaks in 2004, 2007, 2009 (Figure 2) and highlights the issue of MDR-TB concerning migration phenomenon because DR-TB prevalence among foreign born inhabitants was 2.5 times higher $(49.92 \%$ o00) comparing to Portuguese natives $\left(19.51 \%{ }_{000}\right)$. In the last years, TB rates are decreasing in Romania and emigration to other European countries can be considered a cause [14].

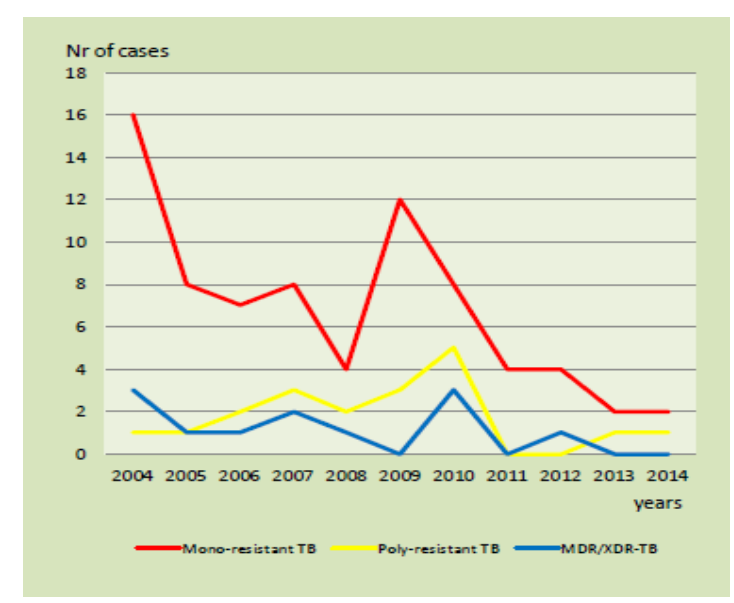

Figure 2.

10 years trend of DR-TB case notifications in Algarve, Portugal; 2004 - 2014

On the other side, as MDR and XDR-TB cases are increasing in Romania, the emigrations phenomena might have an influence on the incidence of drug resistance in countries with lower TB rate and DRTB. Tuberculosis is still underdiagnosed and associated risk factors as smoking, poverty, malnutrition, diabetes, HIV infection can facilitate occupational and 
FARMACIA, 2018, Vol. 66, 3

environmental transmission of MTB resistant strains in exposed workers and in general population $[15,16,17]$. Optimal anti-TB treatment should be envisaged in order to achieve a better prevention and control of TB infection and disease for limiting the extension of MDR migrant TB, that has, currently, such a low rate of cure.

\section{Conclusions}

Our study reveals a high proportion of DR-TB in young adults with a significant migrant pattern of MDR/XDR-TB, including East European foreignborn people. The work force migration may have an important epidemiological impact on TB trend in Algarve, Portugal, a low tuberculosis burden country.

\section{References}

1. Mohajan HK, Tuberculosis is a fatal disease among some developing countries of the world. Am J Infect Dis Microbiol., 2015; 3(1): 18-31.

2. WHO, "Definitions and Reporting Framework for Tuberculosis - 2013 Revision", WHO Press, Geneva. 2013 b.

3. Man MA, Arghir OC, Man S, Streba CT, Olteanu M, Nitu M, Fatal paradoxical cryptic miliary tuberculosis and immune reconstitution disease in a young nonHIV immunocompromised male patient- case report with autopsy findings. Rom J Morphol Embryol., 2014; 55(2): 453-457.

4. Global Tuberculosis Report. Geneva: World Health Organization, 2014.

5. Pyle MM, Relative numbers of resistance tubercle bacilli in sputum of patients before and during treatment of streptomycin. Proc staff Meetings Mayo Clinic, 1947, 22: 465.

6. Ducati RG, Ruffino-Netto A, Basso LA, Santos DS, The resumption of consumption. A review on tuberculosis. Mem Inst Oswaldo Cruz., 2006; 101(7): 697-714.

7. Tomás BA, Pell C, Cavanillas AB, Solvas JG, Pool $\mathrm{R}$, Roura $\mathrm{M}$, Tuberculosis in migrant populations.
A systematic review of the qualitative literature. PLoS ONE, 2013; 8(12): 1-12.

8. Buzan MTA, Pop CM, Raduta M, Eichinger M, Heussel CP, Respiratory tuberculosis in children and adolescents: Assessment of radiological severity pattern and age-related changes within two decades. Pneumologia, 2015; 64(4): 8-12.

9. WHO treatment guidelines for drug-resistant tuberculosis 2016 update. www.who.int.

10. WHO Global Tuberculosis Report, 2014. Available at: www.who.int.

11. European Centre For Disease Prevention and Control (ECDC) Annual epidemiological report. Respiratory tract infections - tuberculosis, 2014. www.ecdc.europa.eu.

12. Soroceanu V, Rais C, Stefanescu E, Brumărel M, Safta V, Adauji S, Priscu V, Taerel AE, Epidemiological and economic aspects of tuberculosis in children. a comparative analysis: Romania vs. The Republic of Moldova. Farmacia, 2016; 64(1): 152-158.

13. Censos Algarve 2011 Resultados Definitivos - Região Algarve. Instituto Nacional de Estatística, I.P, Lisboa, Portugal, 2012. www.ine.pt.

14. Nitu FM, Olteanu M, Streba CT, Jimborean G, Postolache P, Man MA, Trofor AC, Nemes RM, Dragonu L, Olteanu M, Tuberculosis and its particularities in Romania and worldwide. Rom $J$ Morphol Embryol., 2017; 58(2): 385-392.

15. Narasimhan P, Wood J, MacIntyre CR, Mathai D, Risk Factors for Tuberculosis. Pulm Med., 2013; 2013: 1-11.

16. Stratan E, Ţurcan N, Crudu V, Romancenco E, Cotelea T, Niţulescu GM, Chiriţă C, Moruşciag L, Biological evaluation of new 2-phenethylbenzoyl thiourea derivatives as antituberculosis agents. Farmacia, 2018; 66(1): 97-106.

17. Otelea M, Rascu A, Genomics and proteomics techniques in nanoparticles studies - new approach in environmental research. Environ Engineer Manag J., 2015; 14(10): 2283-2291

18. Lien LT, Hang NTL, Kobayashi N, Yanai H, Toyota E, Sakurada S, Thuong PH, Cuong VC, Nanri A, Mizoue T, Matsushita I, Harada N, Higucji K, Tuan LA, Keicho N. Prevalence and risk factors for tuberculosis infection among hospital workers in Hanoi, Vietnam. PLoS ONE, 2009; 4(8): 1-7. 